\title{
THE NARRATIVE OF MARTYRDOM AS A POSTMODERN WAY OF DOING A MODERN LIBERATION THEOLOGY
}

\author{
Albertus Bagus Laksana*
}

\begin{abstract}
The survival and significance of the Latin American liberation theology movement relies, to some extent, on the power of the narratives of martyrdom. Precisely by relying on these narratives, through the dynamics of the theological category of memory that leads to solidarity, liberation theology situates itself in the tension between modernity and postmodernity. The categories of narrative, memory and solidarity, which are at play in the whole dynamic of martyrdom, constitute a postmodern way of doing a modern liberation theology. Liberation theology will only be able to retain its "liberative" and "theological" element insofar as it continues to be "modern" and "postmodern" at the same time. Against the postmodern disbelief in the possibility of human emancipation, liberation theology continues to labor precisely under principium liberationis grounded in the promise of liberation contained in God's revelation in the Scriptures. However, against the "modern" conception of emancipation based on reason and governed by the idea of progress, liberation theology envisions liberation as an integral process which takes place in a concrete, particular historical reality and under the eschatological promise of God.
\end{abstract}

Keywords: Liberation theology, martyrdom, modern, postmodern, narrative, memory, solidarity.

Abstrak: Relevansi dan pertumbuhan teologi pembebasan, sampai tingkat tertentu, juga bergantung pada kekuatan kisah kemartiran. Dengan mendasarkan diri pada kisah (narrative) yang diolah lewat kategori pengingatan (memory) yang mengarah pada solidaritas, teologi pembebasan menempatkan diri dalam tegangan antara modernitas dan

* Albertus Bagus Laksana, Fakultas Filsafat, Universitas Sanata Dharma, Jl. Kaliurang, Km. 7, Kotak Pos 1194, Yogyakarta. E-mail: bagus.laksana@usd.ac.id. 
posmodernitas. Kategori kisah, pengingatan, dan solidaritas, yang berada dalam jantung narasi kemartiran, mengetengahkan sebuah cara posmodern untuk melakukan teologi pembebasan yang modern. Teologi pembebasan hanya akan berhasil mempertahankan unsur "teologi" dan "pembebasan" sejauh bersifat modern dan posmodern pada saat yang sama. Melawan ketidakpercayaan posmodernitas terhadap kemungkinan proyek pembebasan, teologi pembebasan mempertahankan prinsip pembebasan atas dasar isi pewahyuan Allah dalam Kitab Suci. Akan tetapi, melawan pemahaman modern tentang pembebasan berdasarkan akalbudi dan kemajuan, teologi pembebasan memahami pembebasan sebagai sebuah proses integral yang terjadi dalam waktu dan tempat yang nyata, dalam realitas sejarah yang partikular dan dalam kerangka janji eskatologis Allah.

Kata-kata kunci: Teologi pembebasan, kemartiran, modern, posmodern, narasi, pengingatan, solidaritas.

\section{PROLOGUE}

Ana Guadalupe Martinez, a Salvadoran woman guerilla, dedicates her book, Las Cárceles Clandestinas de El Salvador, among others, to a group of martyred Catholic priests and catechists: "Los sacerdotes católicos Rutilio Grande, Alfonso Navarro Oviedo y los various catequistas miembros de la valiente Iglesia Progresista de El Salvador que han sido brutalmente asesinados por la dictadura."1 In the same book, Martinez does not fail to honor Oscar Romero and Ignacio Ellacuría (one of the six murdered Jesuits of the University of Central America, San Salvador) as martyrs. Ellacuria was actually the one who encouraged and helped her to publish her clandestine book in $1978 .^{2}$

1 This Spanish line would translate in English thus: “ [to] The Catholic priets Rutilio Grande, Alfonso Navarro Oviedo and a number of catechists, members of the brave Progressive Church of El Salvador who have been violently murdered by the dictatorship." See Ana Guadalupe Martinez, Las Cárceles Clandestinas de El Salvador: Libertad Por El Secuestro de Un Oligarca (San Salvador: UCA Editores, 1978), p. 7.

2 This book was published by UCA Editores of the Jesuit University of Central America (UCA) in 1978. But it is interesting to notice that given the political situation by then, the book does not bear the name of the publisher. 
Martinez's appreciation and memory of the martyrs is shared by many. Moments after Archbishop Romero was shot dead in 1980, for example, thousand pages has been written in remembrance of his martyrdom. Most recently (February 2015), the Vatican made the historic (long overdue) step to initiate the beatification process of Romero. This dynamic of remembrance has also been true in the case of the murder of six Jesuit priests and their cook and her daughter in 1989. All these memories point to a significant fact that the story or narrative of martyrdom is a living narrative that continues to thrive in the memory of so many people. As these written memories tell, the narrative of martyrdom actually proves to be a motivating factor, which eventually leads many people to the praxis of liberation.

In this essay, I argue that in its very survival, the Latin American liberation theology movement relies, to some extent, on the power of these narratives of martyrdom. Precisely by relying on these narratives which are largely based on the theological category of memory that leads to solidarity, liberation theology situates itself in the tension between modernity and postmodernity. For this reason, we can arguably see liberation theology as "a modern and postmodern" theology, at the same time. But I argue further that the categories of narrative, memory and solidarity, which are at play in the whole dynamic of martyrdom, constitute a postmodern way of doing a modern liberation theology.

It is my thesis that the twofold characteristics (modern and postmodern) belong to the defining characteristics of liberation theology. Thus, liberation theology will only be able to retain its "liberative" and "theological" element insofar as it continues to be "modern" and "postmodern" at the same time. Against the postmodern disbelief in the possibility of human emancipation or liberation, liberation theology continues to labor precisely under principium liberationis. This belief is grounded in the theological promise of liberation contained in God's revelation in the Scriptures. Against the "modern" conception of emancipation based on reason and governed by the idea of progress, liberation theology envisions 
liberation as an integral process, which takes place in a concrete, particular historical reality and under the eschatological promise of God.

In the following section (second section), I try to provide a historical background, which situates liberation theology in the context of modernity and postmodernity. This exposition is meant to serve as the basis of my argument that liberation theology is necessarily modern and postmodern. The third and fourth sections elaborate the theme of martyrdom narrative as a practico-theological category in liberation theology. The focus of the third section is to see how the narrative of martyrdom plays its role in the actual lives of the people in some parts of Latin America-especially El Salvador-where martyrdom is closely related to liberation process. Thus, in this section, martyrdom is treated as a living narrative in the actual process of liberation.

In the fourth section, I attempt to elaborate the narrative of martyrdom as a "postmodern" theological category. Informed by the works of Johann Baptist Metz, I view martyrdom as a narrative, which is capable of motivating so many people along the path of liberation precisely because it presents itself as memory, which leads to solidarity. These theological categories of narrative, memory, and solidarity can be called "postmodern categories" because, as Metz shows, they set themselves against the idealist and rational tendency in "modern" theology. With these categories, Metz attempts to surpass the narrowness and naïveté of modern theology. Thus, it is justified to argue that the narrative of martyrdom — with its categories of memory and solidarity - constitutes a postmodern way of doing liberation theology.

In the final section, some conclusions and relevance of this study will be drawn. Here I argue that in and through the whole dynamics of the narrative of martyrdom, liberation theology manages to renew itself against the backdrop of the Radical Orthodoxy's criticism. Following the dynamics of this narrative, liberation theology envisions the church as a community of resistance, both against the hegemony of state and capitalism understood as a force that disciplines human desire. 


\section{LIBERATION THEOLOGY, MODERNITY, AND POSTMODERNITY}

From a historical perspective, one can say that liberation theology is a "modern and Western theology." It shares some affinities with the general mode of modern thinking, for example, in its belief in both the possibility and necessity of human emancipation. But, it was born in the era when modernity had been already very ill and bitterly challenged. In the 1960's, the modernity project had been under severe attack, coming mainly from many leftist intellectuals and movements. These movements set themselves against capitalism, the most palpable progeny of modernity. As their mission was to overcome capitalism, quite naturally they were drawn to the Leftist ideology or Marxism. They believed that some fundamental insights of Karl Marx, the greatest critic of capitalism on earth, would be very helpful in their attempt at building new alternatives of managing human societies. For some, the alternatives were still in sight, although not crystal clear; but others were more overwhelmed by a sense of pessimism and resignation as they saw no alternative.

The entire dynamics of the history of the Frankfurt School or the Critical Theory provides a good example of how these two streams of attitude toward late modernity or late capitalism developed. The first generations of the Frankfurt School's intelligentsia who managed to survive the Nazi Holocaust and lived in exile (in the USA), ${ }^{3}$ such as Theodor Adorno, Max Horkheimer and Herbert Marcuse, discovered the inherent irony of the project of Enlightenment (or modernity): the further human civilization marches toward progress along the path of reason, the more irrational human society becomes. Long before their sojourns in the United States, Horkheimer and Adorno already witnessed

3 For some years they resided in New York city and California; and their Institute of Social Research was loosely associated with Columbia University, an association which stirred a heated controversy since it was the only Marxist institute of research in the Western world, which was offered help by an American university whose president was a very conservative intellectual. For further information on this topic, see Zoltan Tar's introduction to Foundations of the Frankfurt School of Social Research, edited by Zoltan Tar and Judith Marcus (New Brunswick and London: Transaction Books, 1984), p. 8ff. 
the great disaster haunting human civilization: Nazism and its eventual Holocaust.

Their experience of Nazism and their analysis of current situation of late capitalist society led those Marxist intelligentsia to discard all hopes of human project of social renewal, be it revolutionary hope provided by Marxism or democratic-capitalistic hope offered by Enlightenment. In the words of Leszek Kolakowski, Dialectic of Enlightenment, a book co-authored byHorkheimer and Adorno, viewed the question of Nazism "not simply as a monstrous freak but rather a drastic manifestation of barbarism into which humanity was falling." ${ }^{4}$ Enlightenment, with all its values, which had lifted humanity out of barbarism, now turned humanity into a new barbaric era. For Horkheimer and Adorno, this tragic development was not shocking because, in their view, this barbarism pertained to the very dialectic of Enlightenment itself. By the word "Enlightenment" they did not refer specifically to the " $18^{\text {th }}$ century Enlightenment" but to "the most general sense of progressive thought [...] aimed at liberating men from fear and establishing their sovereignty." ${ }^{5}$

Together with Eclipse of Reason, ${ }^{6}$ Dialectic of Enlightenment revealed the fear and disillusion of its authors in the face of the barbaric episode of humanity, a period where there was no hope that the "human subject" would ever be able to overcome the power of manipulation in a totally bureaucratized society, the necessary by-product of late capitalism. However, this sense of pessimism was not shared by Jürgen Habermas, the most important of the Frankfurt School's second generation intellectuals. He embarks on a philosophic mission to rescue the project

4 See Leszek Kolakowski, "The Frankfurt School and Critical Theory" in Foundations of the Frankfurt School of Social Research, eds. Zoltan Tar and Judith Marcus, p. 108.

5 See Max Horkheimer and Theodor W. Adorno, Dialectic of Enlightenment (New York: Seabury Press, 1972), p. 3; quoted in Kolakowski, "The Frankfurt School and Critical Theory," p. 108.

6 This book, authored by Horkheimer himself, attacks positivism, pragmatism and scientism. See Zoltan Tar and Judith Marcus, eds., Foundations of the Frankfurt School of Social Research, p. 10. 
of modernity and Enlightenment, not through instrumental reason, but through what he calls "communicative reason."

When liberation theology was born in the 1960s, many of its theologians shared much of the social analysis of Horkheimer, Adorno and Marcuse. These theologians lived and continue to live in the miserable societal realities brought about largely by capitalism: poverty, destitution, injustice, victims, civil wars, bloody revolutions, etc. They found themselves surrounded by some grave problems emerged from "modernidad en crisis." ${ }^{7}$ But, for the liberationists, these historical realities generated hopes, instead of resignation and despair. Thus, they did not follow the path of pessimism and despair taken by some leftist intellectuals as Horkheimer and Adorno. However, liberationist hope has never been based on the bourgeois logic of Habermas's theory of communicative action. In this respect, these theologians returned to the fundamental Christian hope in the narrative of Jesus. But, as they knew all too well that the ills they faced were produced by capitalism, they also drew, quite naturally, some inspirations from Marxism, being the most comprehensive critique of capitalism. In contrast to Horkheimer and Adorno who had lost their faith in Marxism, however, these theologians found in Marxism a critical instrument for social analysis. Thus, in short, the hope generated by the Jesus narrative was supplied by social analysis provided in large part by Marxism. With these two tools at their disposal, they embarked on a project of human liberation, especially for the poor, the victims of capitalism and modernity in crisis.

As can be seen quite clearly, liberation theology retrieves the viability and possibility of the modern project of emancipation, but not through the power of instrumental reason generated by Enlightenment, but

7 On the specific relationship between Gutierrez's liberation theology and modernity, see Marcelo Horacio Labèque, Liberación y modernidad: Una relectura de Gustavo Gutiérrez (Freiburg: Universitätsverlag Freiburg Schweiz, 1997). Labèque prefers the term "modernidad en crisis" to "postmodernidad." He understands Gutiérrez's theology of liberation as an attempt to respond to "los desafios de una modernidad en crisis." See p. 21. 
through the under side of "modern capitalist reality," that is, the irruption and the power of the poor, to borrow Gustavo Gutiérrez's phrase. This move is dictated both by the reality of the poor itself-with the help of Marxist social analysis-and by what liberation theologians call "God's preferential for the poor."

Therefore, liberation theology can be called "modern" in the sense that it continues to believe in the possibility and necessity of human liberation in order to provide room for human persons to become subject in history. But, it differentiates itself from "modernity" as it understands liberation and subjectivity differently. In liberation theology, liberation and subjectivity can only be achieved in their fundamental connection with the poor (victims) and God. Thus, liberation theology did not fight for a modern-bourgeois emancipation. In this respect, it has to be noted that liberation theology distances itself from other strands in Christian "modern" theologies, such as that of Schleiermacher. Liberation theology does not respond to the "rational or ideological" effect of modernity, for example in the problem of modern atheism (or to borrow Schleiermacher's well-known phrase: to Christianity's "cultured despisers"). Rather, it responds to the "social" effect of modern (late) capitalism. In this context, liberation theology can be seen as "a demystifying critique of theologies of modernity and of their complicity with modernity-the modernity of colonialism, and neocolonialism, of the genocide of the Amerindian, Africans, and Jews, of the subordination of women and of the so-called heathen-pagan." 8

However, precisely in its critiques of modernity, liberation theology anticipates postmodernism. ${ }^{9}$ The liberationist and postmodernist paths converge on their reservation about the modernist understanding of

8 See David Batstone et al., Liberation Theologies, Postmodernity, and the Americas (London, New York: Routledge, 1997), p. 12.

9 Throughout this essay, I understand postmodernity as a general "philosophical" sensibility that sets itself over against modernity. As for its specific criticisms of modernity, I follow David Batstone et al.: postmodernity is marked by the selfaffirmation and naming of the Other, historicization of history, significance of language, emphasis on technology, fragmentation of the subject, question of 
rationality and subjectivity. In various different ways, both movements attempts at decanonizing universal truth-claims with an appeal to the contingencies of time and place (historical reality). Thus, they set some new limits to rationality and subjectivity. Both liberation theology and postmodernism know how to celebrate fragments of local knowledge, freeing themselves from modernity's obsession with universalization. ${ }^{10}$ Instead of universality, they seek and respect otherness and alterity. Seen from the perspective of liberation theology, the advent of postmodernism seems to be able to strengthen its concern for the poor, the Other, historicity, particularity and contextuality of theology, and the retrieval of indigenous religiosities.

But, one should not fail to notice the fact that liberation theology does not share all postmodern claims. It rejects postmodern "death of the subject" and its overall pessimism and atheism. Even when it comes closer to postmodernity, liberation theology will never be willing to give up its fundamental belief in the possibility and necessity of liberation in history as these are demanded by the specific historical reality of the poor and God's revelation.

In the following section, I attempt to describe how the narrative of martyrdom works and functions in the praxis and discourse of liberation theology. I would argue that precisely in and through this narrative of martyrdom, liberation theology presents itself as a modern theology done in a postmodern way.

\section{THE MIRACLE OF MARTYRDOM}

When the Vatican announced the appointment of Oscar Romero as the new archbishop of San Salvador in 1977, the progressive element within the Roman Catholic Church of El Salvador was stunned. "They knew Oscar Romero, then bishop of Santiago de Maria, as a timid and

perception, the death of the "intellectual," the suspicion of any "revolutionary" project, demystifying of fetishisms, and the death of history. See David Batstone et al., Liberation Theologies, pp. 9-11.

10 See David Batstone et al., Liberation Theologies, p. 14. 
conservative man, a follower of Opus Dei whom the Papal Nuncio reportedly had recommended for the archdiocese after consultation with businessmen, government officials, military officers, and women of the upper reaches of Salvadoran society," wrote Theresa Whitfield. ${ }^{11}$ This assessment of Romero's personality was shared by many. Romero had the reputation for being a conservative prelate and a staunch adversary of liberation theology. Certainly, by the time of his appointment, he was not considered the best person to lead the Catholic Church of El Salvador during the times of deep crisis.

However, not long after his installation as archbishop of San Salvador, contrary to all predictions, this very man shocked everybody, on the left and on the right alike, as he was transformed by the so-called "the miracle of Rutilio."12 Rutilio Grande, a simple Jesuit parish priest of Aguilares, was the first murdered priest in El Salvador. He was known to be Romero's close friend..$^{13}$ Grande was a very virtuous, zealous, and deeply believing priest. For this, he had Romero's high respect. ${ }^{14}$ But, on the other hand, he had been a "problem" for Romero as his pastoral approaches at Aguilares looked "incorrect and mistaken" (progressive). So, Grande was like an enigma for Romero. Apparently, only his death managed to solve this enigma. Grande was gunned down in 1977 in the midst of doing his ministry among the poor. Almost like a miracle, Grande's martyrdom led Romero to his "conversion" as it opened his conscience to the fact that what Grande had been doing was right. ${ }^{15}$ From that moment on, Romero had never been the same. He changed into a very progressive archbishop, fearing nothing and nobody but God. The Jesuit

11 Teresa Whitfield, Paying the Price: Ignacio Ellacuria and the Murdered Jesuits of El Salvador (Philadelphia: Temple University Press, 1995), p. 102.

12 Teresa Whitfield, Paying the Price, p. 104.

13 Teresa Whitfeld writes that Rutilio Grande served as a master of ceremonies at Romero's own episcopal ordination in 1970 and a priest to the very marrow of his bones. Teresa Whitfield, Paying the Price, p.104.

14 See Jon Sobrino, Archbishop Romero: Memories and Reflections (Markynoll: Orbis Books, 1990), p. 9.

15 For more comprehensive account on this, see Jon Sobrino, Archbishop Romero, p. 9ff. 
liberation theologians, his former principal adversaries, now turned to be his most trusted mentors and theologians as he tried to envision the new ways of leading the Church in crisis.

The final hours of Romero's journey of conversion have been wellknown. At the end of the day, he had to accept the gift of martyrdom, the same gift granted to his beloved priest, Rutilio Grande. He was shot dead at about 6:30 P.M. on March 24, 1980. In the context of my argument in this essay, it is crucial to see how the narrative of Grande's martyrdom had worked in the life of Oscar Romero. It has been referred as "the miracle of Rutilio." But, this miracle can be explained in a more concrete and visible way. Grande's martyrdom presented itself as a living narrative, a narrative marked by blood. This narrative had the power to move and transform Romero's heart and mind precisely because of its very concreteness, its being too "real" to be refused, too bloody to be banished from a good Christian conscience. Until the death of Grande, liberation theology had not been able to convince him. Jon Sobrino loves to tell the story of how Romero listened to his talk one day on the problem of the historical Jesus and the Reign of God-a typically liberationist Christology —without even bothering to look at Sobrino's face for a second. ${ }^{16}$ Romero used to call liberation theologians "Marxist" and accused liberation theology of being a false ideology. Thus, the martyrdom of Rutilio Grande provided what liberation theology had been lacking.

In the wake of Romero's death, this "miracle of Rutilio" continued, but it changed itself into "the miracle of Romero." The narrative of his martyrdom touched so many people in El Salvador, not to mention many others around the globe, especially in Christian circles. But, it is crucial to notice that this narrative eventually led some Christians to the path of martyrdom. For example, the Jesuits at the University of Central America "José Simeón Cañas" (UCA) took the narrative of Romero's martyrdom seriously. His death strengthened their struggle for liberation, the struggle that had been led by Romero himself after his conversion. 
Eventually they set a pastoral center in memory of him at the UCA, the same university that granted Romero an honorary doctorate. These two gestures manifest only superficially a much deeper appreciation of the UCA Jesuits toward Romero. In the words of Ignacio Ellacuría, "With Archbishop Romero, God has visited El Salvador."17 That was how the future Jesuit martyrs expressed their respect for Romero. Until his own martyrdom, Ellacuría had been profoundly inspired by Romero's narrative of life and death. Romero was "the maestro of his heart, praxis, and spirituality." 18

On the fateful night of November 16, 1989, right after they shot six Jesuits at the UCA, including Ellacuría, the murderers entered and destroyed the Pastoral Center in the same compound where they found a large portrait of Romero. ${ }^{19}$ These murderers knew all too well the influence of this man on the six priests they killed few minutes before. Probably, they wanted these "leftist clergymen" to be united in a more visible way, that is, through the shedding of their blood.

Thus, the narrative of martyrdom keeps being told in the lives and deaths of some people. The names of the martyrs continue to be engraved on the hearts and memories of so many people. As has been shown in the very beginning of this essay, the story of Ana Guadalupe Martinez points to this fact, that is, the power of the narrative of martyrdom in the lives of those who struggle for liberation. Through the power of this very narrative, liberation theology presents itself as a way of doing modern

17 See Jon Sobrino, Archbishop Romero, p. 204. This book in itself constitutes a palpable evidence of Romero's influence on the UCA Jesuit in general and Jon Sobrino in particular.

18 See Kevin F. Burke, The Ground Beneath the Cross: The Theology of Ignacio Ellacuria (Washington, D.C.: Georgetown University Press, 2000), p. 24. Burke quotes Jon Sobrino as saying that "I have no doubt that Ellacuria was really and existentially affected by Monseñor Romero, but in a way that differed from a Rahner or a Zubiri. Monseñor's prophecy and mercy, his sense of utopia and freedom, left clear footprints on him. But in my opinion, the deepest and most specific influence was something else: Monseñor Romero's profound faith in the mystery of God, about which he spoke unaffectedly and naturally, and which he embodied in his person."

19 See Teresa Whitfield, Paying the Price, p. 13. 
theology in a postmodern manner. I try to elaborate this point in the next section of this essay.

\section{MARTYRDOM AS A MODERN-POSTMODERN CATEGORY}

As I have pointed out earlier, liberation theology is a "modern" theology insofar as it retains some fundamental features of the modern project, especially its belief in the possibility and necessity of human emancipation within a larger project of the human becoming as subject. Although some postmodern thinkers believe that these two features have a totalizing tendency and have been based largely on myths, liberation theology has continued to be resolute in their fight for human liberation and human subjectivity. In this respect, liberation theology has no other choice since these two features constitute the fundamental messages of God's revelation in history (as it is recorded in the Bible). For Johann Baptist Metz, political theology — which shares some basic premises with liberation theology - has to be a "political theology of the subject," provided that "the human as the subject" here are not understood in the bourgeois sense. ${ }^{20}$ Here, Metz follows what the religion of the Bible reveals, "that all people might become political subjects of faith and theology." This means that they can attain their identities as subjects only in relation to God. Christianity can only function in this process when it retrieves its messianic sting and refuses to be enchanted with the spell of bourgeois ideologies of wealth and personal comfort. In the context of the situation "after Auschwitz," Metz understands political theology as a new way of doing theology from the perspective of, and for, the victims of history, with a practical intent to restore the victims' subjectivity through memory and narrative.

In his new political theology, Metz retains some features of modernity (or Enlightenment) while at the same time criticizes modernity for its banal conception of human emancipation and subjectivity. Metz's project

20 See Johann Baptist Metz, Faith in History and Society: Toward a Practical Fundamental Theology (London: Burns and Oates, 1980), pp. 32-48. 
is to rescue the victims of history from this banality, which, among others, has led humanity to Auschwitz. This concern is shared by his fellow "political" liberationists from the Southern Hemisphere. Liberation theology works under the premise of God's promise and imperative for the human emancipation as subject in history, a history that is marked by modernity's illnesses.

However, as one can see quite clearly, Metz's political theology and Latin American liberation theology, while retaining some modern features, discover some new ways to conceive and do theology in a "postmodern" way. In Metz, these new ways can be seen in his explicitly new "categories" in what he calls "practical-fundamental theology": memory, narrative, and solidarity. ${ }^{21}$ We can find none of these categories in any modern theology before. In my view, these three categories are of great help for us in our attempt to reflect on the narrative of martyrdom in liberation theology. Therefore, I will take some insights from Metz's argument, in a view to retrieve some postmodern features at play in the narrative of martyrdom. ${ }^{22}$

As discussed in the previous section, the narrative of martyrdom operates as a narrative of life, which presents itself as memory and moves people to act in solidarity with the martyrs and those for whom the martyrs shed their blood. These three categories can be seen as postmodern in the sense that they go beyond modern categories in theology.

In the story of martyrdom, the category of narrative displays some postmodern features as it presents human emancipation not as a pro-

21 See Johann Baptist Metz, Faith in History and Society, pp. 184-237.

22 The main reason of why I take Metz's ideas on this specific problem, rather than one of many liberation theologians, is that in his theology these three categories are expressed and elaborated in a systematic and comprehensive manner in relation to Enlightenment and modernity. In my view, so far there has been no liberation theologian who treats these categories in such depth. By taking Metz's insights, however, I do not pretend to simply juxtapose his political theology and liberation theology. Although these two theologies share much in common, they differ in many ways. But, I believe that in these categories, Metz is very much helpful to liberation theology. 
gressive human emancipation based on transcendental and argumentative reason. For Metz, the category of narrative with a practical intent will rescue Christianity from a transcendental-idealist tendency. ${ }^{23}$ Narrative will connect people with a particular experience of salvation or emancipation in its richness as living experience, not with an abstract idea of salvation. The "uniqueness" and the "newness" of this experience can only be laid out and made present in a narrative way. The narrative of martyrdom points to the concrete and real experiences of the martyrs and their communities, experiences that are marked by interruptions and disruptions, catastrophes and tragedies, but also by hope against all hopes. Liberation is not presented as something abstract, universal and timeless, but as a real, historical and particular struggle. In the words of Jon Sobrino, "For liberation theology, martyrdom is not a concept, but a reality." 24 The stories of martyrdom endow liberation praxis the positive power of light and energy. These stories narrate liberation praxis of faith in a distinctive way as to make faith credible and reasonable.

As noted previously, the narrative of martyrdom presents itself as a kind of memory or remembrance. The power of this narrative rests not on the "self-consciousness" of the persons but rather on their capacity to remember (memory). In a sense, political theology and liberation theology retrieve the category of memory as an important category for theology. As Metz has pointed out, modern theology banished this category as it followed the track of Enlightenment's prejudice against memory. This prejudice sprang from the spirit of Enlightenment summed up by Immanuel Kant's dictum "Sapere Aude!" which means "have the courage to use your own reason independently." 25 This autonomous reason was the sine qua non condition for the human to reach maturity (mündigkeit). In its actuality, this dictum was set against all that was connected with

23 See Johann Baptist Metz, Faith in History and Society, pp. 205-228.

24 See Jon Sobrino, Witnesses to the Kingdom: The Martyrs of El Salvador and the Crucified Peoples (Maryknoll: Orbis Books, 2003), p. 102.

25 Here I follow Dermot A. Lane's interpretation of Metz in his "Memory in the Service of Reconciliation and Hope," in Truth and Memory: The Church and Human Rights in El 
the past, especially as expressed in tradition and religion. This tradition of the past had been considered a hindrance to the autonomous reason of the enlightened human. Since memory was perceived to be associated exclusively with the past, it had to be removed from human reason. As a result, modernity and modern theology marched forward with a crippled understanding of reason.

Through his new political theology, Metz attempts to rediscover "the primacy of a reason endowed with memory, that is, anamnestic reason." 26 Against the Enlightenment's diminished conception of reason, he offers an antidote taken from biblical Judaism. In his view, the removal of reason from memory can be traced back to the time when Christianity was Hellenized and taken further away from its roots in Judaism. For him, "the great difference between the biblical world of Judaism and contemporary modern world lies precisely in this lack of memory in the modern world." ${ }^{27}$ Biblical faith is a faith that is based on memory. The Israelites found the salvific works of Yahweh only as they reflected back on their past histories as God's people. They came to understand the Exodus narrative as God's liberative act in history only when they used their memory. In the final analysis, the Exodus narrative became a salvific memory.

According to Metz, this memory has a specific characteristic of being "dangerous" (dangerous memory). In this respect, he takes up the insight of Walter Benjamin, a Jewish philosopher and literary critic, one of the Frankfurt School's celebrated intellectuals. In the words of Mary Grey, Benjamin's invention of "dangerous memory" can be seen as a foreshadow

Salvador and Guatemala (Herefordshire: Gracewing, 2001), eds. Michael A. Hayes and David Tombs, p. 182.

26 See J. B. Metz, "The New Political Theology: The Status Quaestionis," in his A Passion for God: The Mystical-Political Dimension of Christianity, translated by J. Matthew Ashley (New York, Mahwah: Paulist Press, 1998), p. 25; quoted in Dermot A. Lane, "Memory in the Service of Reconciliation and Hope," p. 182.

27 See J. B. Metz, "Freedom and Solidarity: the Rescue of Reason," in Faith and the Future: Essays on Theology, Solidarity and Modernity (New York: Orbis Books, 1995), eds. J.B. Metz and J. Moltmann, p. 76; quoted in Dermot A. Lane, "Memory in the Service of Reconciliation and Hope," p. 182. 
of the postmodern challenge to objectivity in history and the impossibility of capturing the "how it really was" of an event. ${ }^{28}$ Thus, for Benjamin, to recover the past means "to seize hold of a memory as it flashes up at a moment of danger." ${ }^{29}$ For Metz, memory is dangerous as it "breaks through the magic circle of prevailing consciousness." ${ }^{30}$ This danger would force the human to establish a common solidarity based on the memory of the history of suffering, especially the sufferings of those who have been annihilated.

As discussed in the previous section, the lives of the martyrs as narratives enter the hearts and minds of people through the category of anamnestic reason (memory), not argumentative reason. And, this memory proves itself to be a "dangerous memory" as Benjamin and Metz rightly call. Grande's martyrdom broke the prevailing consciousness of the then conservative Archbishop Romero. The blood of Romero, in turn, has continued to move so many hearts along the path of martyrdom, resisting every barrier and overcoming every challenge. As dangerous memory, the narrative of martyrdom refuses every kind of reification in the area of faith and liberation. In this way, they experience faith as something new and fresh as it continues to incarnate in reality. They reject every temptation to be "sublated" under the reified categories of bourgeois ideology: prosperity, personal security, self-fulfillment, etc. Instead, they attempt to become bearers of the dangerous memory of martyrdom. With their laments, tears, sweats and blood, they march forward along the path of the struggle of liberation.

Thus, the narrative of martyrdom as dangerous memory leads eventually in the act of solidarity. But, it has to be noted, this solidarity should not be understood in the framework of bourgeois categories of equality and reciprocity as these seem to appear in Habermas's theory

28 See Mary Grey, "A Theology for the Bearers of Dangerous Memory," in Truth and Memory, eds. Michael A. Hayes and David Tombs, p. 163.

29 See Walter Benjamin, "Theses on the Philosophy of History," in his Illuminations, edited and introduced by Hannah Arendt (New York: Shocken Books, 1969); quoted in Mary Grey, "A Theology for the Bearers of Dangerous Memory," p. 163.

30 See Johann Baptist Metz, Faith in History and Society, p. 90. 
of communicative action. ${ }^{31}$ Rather, it is a solidarity for those who suffer. Metz understands solidarity as a category of assistance, of supporting and encouraging the subject in the face of that which threatens him or her most acutely and in the face of his or her suffering. ${ }^{32}$ The narrative of martyrdom possesses some power to drive people into this kind of solidarity precisely because it is a narrative of suffering. The martyrs are those who are threatened by suffering in a fundamental and terminal way. From a superficial point of view, the death of the martyr seems to be the final annihilation of his/her subjectivity. But, the martyrs themselves understand their deaths as the true fulfillment of their subjectivity. Moreover, the memory of and solidarity to the martyrs as well as to all those who suffer rescue them from total annihilation, that is, annihilation from history.

\section{EPILOGUE}

I have attempted at showing how the narrative of martyrdom functions in the lives of the people in the context of Latin American liberation theology. As a narrative, martyrdom has been able to motivate people in their real struggle for liberation; in memory of this narrative, people are driven to act in solidarity with those who suffer; and thus, they continue with their liberation praxis. In this way, liberation theology presents itself as a dynamic of narrative, memory and solidarity. As we have seen, for Metz, these three categories should be viewed precisely as critiques of "modern and liberal" theologies, which had been inspired largely by Enlightenment (modernity). In this line of thought, these categories can be seen as "postmodern" categories in theology.

But, these categories can only function properly as theological categories insofar as liberation theology continues to retain its "modernist" belief in the possibility and necessity of liberation of the poor and the victims. Therefore, these categories cannot be thoroughly postmodern.

31 See Johann Baptist Metz, Faith in History and Society, p. 233.

32 Johann Baptist Metz, Faith in History and Society, p. 233. 
Rather, they constitute a "postmodern way" of doing liberation theology, which continues to be a "modern" theology. In reality, this postmodern way proves to be working well. It helps liberation theology both to be more and more "liberative and theological" in the real praxis of the people. There is no more consoling fact for liberation theology than this fact precisely because the aspects of "liberation" and "theology" rightly belong to its very identity.

The narrative of martyrdom also helps liberation theology to come to terms with the criticism of the Radical Orthodoxy as, for example, expressed by Daniel Bell Jr. in his latest book, Liberation Theology After the End of History. ${ }^{33}$ Bell Jr. argues that liberationist failure in its battle against capitalism lies in its inadequate ecclesiology. In his view, liberationist ecclesiology is not radical enough as it envisions the church of the poor as an indirectly political church, while the state is endowed with revolutionary expectations. Liberationist view of politics as statecraft is both naïve and unrealistic, given our awareness that capitalism's victory is ontological, that is, through its power to discipline human desire. Capitalism does not work through the state, but it governs human desire through the state-form mechanism, which surpasses the state. ${ }^{34}$ Thus, liberationist ecclesiology falls into the trap of modern narrative that divorces religion from the socio-political sphere of life and fails to recognize the root of the problem. As the antidote, the liberationists should refuse politics as statecraft and reclaim the church as a fully social,

33 Daniel Bell Jr., Liberation Theology After the End of History: The Refusal to cease suffering (London \& New York: Routledge, 2001), passim.

34 Viewed against the backdrop of Deleuze's and Foucault's thought, this understanding of politics as statecraft looks thoroughly inadequate. In Bell's view, these French philosophers help us to understand that capitalism's victory is not merely economic, but ontological. Bell argues, "Capitalism extends its reign by far more than merely fostering a particular mode of production and division of labor; it is best understood as an ensemble of technologies that disciplines the constitutive human power of desire; of particular importance is the recognition that capitalism advances as the state-form delivers desire to its discipline." Daniel Bell Jr., Liberation Theology After the End of History, p. 3. 
political, economic reality in its own right. Only in this way, would the church be able to fight against capitalism on the level of human desire.

Against the backdrop of Bell Jr.'s criticism, I argue that the narrative of martyrdom indeed plays the role of disciplining human desire. As memory, it penetrates the private sphere of human desire and moves this desire into the direction of socio-political solidarity. As we have seen in the case of some guerilla activists, this narrative does not necessarily presuppose an understanding of politics as statecraft. They fight against the state. In general, the narrative of martyrdom cannot be understood fully if one divorces it from "politics." In Latin America, martyrdom has been a form of resistance against the hegemony of state. In fact, the church as a community, which bears the dangerous memory of martyrdom, continues to be a community of resistance. It sets itself against the state machinery, which has been responsible for the martyr's death. Otherwise, Grande's martyrdom would not have been followed by Romero's. In its resistance, the Church of the martyrs (ecclesia martyrum) goes beyond the state. It does not only reject to share the state's narrative of victory and its solidarity among victors, but it creates its own narrative, memory, and solidarity. In this sense, it tries to discipline human desire without relying on the power of the state.

Thus, in and through the narrative of martyrdom, liberation theology appears to be a modern theology which has been done in a postmodern manner, both in its resistance against the socio-economic disease of modernity (found in poverty) and the ontological disease (in savage capitalism).

\section{REFERENCES}

Batstone, David, et al. Liberation Theologies, Postmodernity, and the Americas. London and New York: Routledge, 1997.

Bell Jr., Daniel. Liberation Theology After the End of History: The Refusal to cease suffering. London and New York: Routledge, 2001.

Benjamin, Walter. Illuminations. Edited and introduced by Hannah Arendt. New York: Shocken Books, 1969. 
Burke, Kevin F. The Ground Beneath the Cross: The Theology of Ignacio Ellacuria. Washington, D.C.: Georgetown University Press, 2000.

Hayes, Michael A. and David Tombs, eds. Truth and Memory: The Church and Human Rights in El Salvador and Guatemala. Herefordshire: Gracewing, 2001.

Horkheimer, Max and Theodor W. Adorno. Dialectic of Enlightenment. New York: Seabury Press, 1972.

Labèque, Marcelo Horacio. Liberación y modernidad: Una relectura de Gustavo Gutiérrez. Freiburg: Universitätsverlag Freiburg Schweiz, 1997.

Martinez, Ana Guadalupe. Las Cárceles Clandestinas de El Salvador: Libertad Por El Secuestro de Un Oligarca. San Salvador: UCA Editores, 1978.

Metz, Johann Baptist. Faith in History and Society: Toward a Practical Fundamental Theology. Translated by David Smith. London: Burns and Oates, 1980. . A Passion for God: The Mystical-Political Dimension of Christianity. Translated by J. Matthew Ashley. New York and Mahwah: Paulist Press, 1998.

Metz, J. B. and J. Moltmann. Faith and the Future: Essays on Theology, Solidarity and Modernity. New York: Orbis Books, 1995.

Sobrino, Jon. Archbishop Romero: Memories and Reflections. Markynoll: Orbis Books, 1990.

. Witnesses to the Kingdom: The Martyrs of El Salvador and the Crucified Peoples. Maryknoll: Orbis Books, 2003.

Tar, Zoltan and Judith Marcus, eds. Foundations of the Frankfurt School of Social Research. New Brunswick and London: Transaction Books, 1984.

Whitfield, Teresa. Paying the Price: Ignacio Ellacuria and the Murdered Jesuits of El Salvador. Philadelphia: Temple University Press, 1995. 